\title{
Strategi Kepemimpinan Kiai dalam Membentuk Karakter Aswaja
}

\author{
Rustam \\ UIN Sunan Kalijaga Yogyakarta, Indonesia \\ rustamnawawi1985@gmail.com
}

Abstrak:

Penelitian ini mengulas Strategi Kepemimpinan Kiai dalam Membentuk Karakter Aswaja di Pondok Pesantren An Nur, Ngrukem, Bantul, Yogyakarta. Jenis penelitian ini adalah penelitian lapangan dengan menggunakan pendekatan kualitatif. Sumber data penelitian ini diambil dari Metode pengumpulan data seperti: pertama, pengamatan atau observasi langsung beberapa kali, kedua, Wawancara dengan pimpinan pesantren, pengurus, pengajar, santri, dan warga sekitar pesantren, dan 3). Sedangkan dokumentasi diambil dari kajian field research berbagai informasi yang terkait. Hasil penelitian menunjukkan bahwa segala tindakan dan aktivitas kegiatan yang dilakukan civitas pesantren (Dewan Dzuriyah, pengurus, ustad, dan santri) di Pondok Pesantren An Nur, Ngrukem, Bantul, Yogyakarta yang tidak hanya menghafalkan AlQur'an, namun juga membentuk karakter Aswaja kepada para santri.

Kata Kunci: Strategi Kepemimpinan, Karakter Aswaja, Pondok Pesantren

\begin{abstract}
:
This study examines the Kiai's Leadership Strategy in Forming Aswaja's Character in An Nur Islamic Boarding School, Ngrukem, Bantul, Yogyakarta. This type of research was field research using a qualitative approach. Sources of data for this study were taken from data collection methods such as: first, direct observation or observation several times. Second, interviews with boarding school leaders, administrators, teachers, students, and residents around the boarding school. Third, documentation taken from field research studies with various related information. The results showed that all actions and activities carried out by the boarding school community (Dzuriyah Council, administrators, cleric, and students) at An Nur Islamic Boarding School, Ngrukem, Bantul, Yogyakarta not only memorized the Al-Qur'an, but also formed the character of Aswaja to the students.
\end{abstract}

Keywords: Leadership Strategy, Aswaja Character, Islamic Boarding School 
Rustam

\section{Pendahuluan}

Bangsa Indonesia telah memasuki era industri 4.0 yang akan berdampak pada eksistensi pondok pesantren sebagai lembaga pendidikan Islam yang sudah ada sejak beberapa abad silam di bumi nusantara jauh sebelum Indonesia merdeka, sebuah lembaga yang mewarisi misi dakwah walisongo dengan ciri khasnya itu sebagai wujud dari perkembanagan sistem pendidikan nasional. Pondok pesantren sebagai lembaga pendidikan Islam di bumi nusantara, diharapkan dapat mengikuti perkembangan zaman. Pesantren dapat membekali para santri dengan kemampuan nyata melalui pendidikan. ${ }^{1}$

Derasnya pengaruh industri 4.0 dengan kecanggihan digital yang semuanya dinina bobokkan dan termasuk budaya luar sangat mudah diakses oleh generasi muda, sehingga hal ini juga sangat mempengaruhi kepribadian mereka. Belum lagi masalah ujaran kebencian, penyebaran berita hoax, saling fitnah, menjamurnya radikalisme dalam agama, dan belum lama ini masalah rasisme terhadap sesama anak bangsa di tengah masyarakat yang plural.

Sederet potret realita permasalahan nasional itu, keberadaan diharapkan pesantren diharapkan mampu mengurai permasalahan bangsa dan turut mencerdaskan anak bangsa dengan cara memberikan pendidikan yang berkualitas dan pondasi karakter Aswaja kepada para santri agar nantinya menjadi sumber daya manusia (SDM) yang unggul dalam mengisi kemerdekaan Republik Indonesia (RI) di era digital dewasa ini dan merawat kebenekaan dalam bingkai Negara Kesatuan Republuk Indonesia (NKRI). Oleh karena itu, upaya untuk membangun karakter bangsa dibutuhkan pendidikan karakter. ${ }^{2}$ Pendidikan karakter dalam Praktiknya, santri diajarkan bagaimana bersikap yang benar ala njawani (sesuai adat istiadat Jawa), bertutur kata dengan bahasa yang santun, bertingkah laku dengan penuh tata krama, baik sesama santri maupun terhadap tamu, lebih-lebih terhadap keluarga pimpinan pesantren. ${ }^{3}$

Sistem pendidikan pesantren ini membuahkan kuatnya homogenitas watak dan pemikiran keislaman di Indonesia dibuktikan sekitar abad ke-13 dan abad ke-20. Aspek pemikiran ushul fiqih Imam Syafi'i, pemikiran tauhid Abu Musa Al-Asy'ari, dan pemikiran tasawuf Syekh Juneid. ${ }^{4}$ Menelisik dari aspek historisnya, pesantren memiliki karakteristik yang tidak hanya identik dengan makna keislaman semata, namun juga terdapat unsur keaslian (ontentik) Indonesia (indigenous). ${ }^{5}$ Pesantren menggunakan sistem nilai yaitu alhlul sunnah

\footnotetext{
${ }^{1}$ Nurcholis Madjid, Bilik-bilik Pesantren Sebuah Potret Perjalanan, (Jakarta: Paradigma, 1997), 17-18.

${ }^{2}$ Maragustam, Filsafat Pendidikan Islam, (Yogyakarta: FITK UIN Sunan Kalijaga,2018), 248.

${ }^{3}$ Rustam dan Ahmad Shofiyuddin Ichsan, "Pendidikan Islam Berbasis Kearifan Lokal", IQRO: Journal of Islamic Education Vol. 3, No.1, Juli 2020. 1-14

${ }^{4}$ Rustam dan Ahmad Shofiyuddin Ichsan, "Pendidikan Islam Berbasis Kearifan Lokal”, 49.

${ }^{5}$ Rustam dan Ahmad Shofiyuddin Ichsan, "Pendidikan Islam Berbasis Kearifan Lokal”,3.
} 
wal jamaah. ${ }^{6}$ Peran kepemimpinan kiai dalam memelihara tradisi pesantren yang lekat dengan sosok kepemimpinan kiai yang mampu memelihara dan mengembangkan kajian keislaman. Para kiai sebagai pelaku sejarah yang telah berhasil membimbing umat Islam Indonesia dengan taat menganut paham alhlul sunnah wal jamaah. ${ }^{7}$ Keberhasilan itu tidak lepas dari strategistrategi para kiai dalam penggemblengan karakter santrinya.

Posisi kiai sebagai pemimpin pesantren juga diharuskan untuk menjunjung tinggi nilainilai luhur yang menjadi acuan dalam perilaku dan pengembangan pesantren. ${ }^{8}$ Oleh karena itu, keberadaan kepemimpinan kiai yang mampu menyesuaikan posisi dirinya sebagai pemimpin, penjaga kustodian, guru dan mentor untuk siswa, dan suami dan ayah di keluarga mereka sendiri yang juga menetap di pondok. Tradisi kearifan lokal yang berkembang di masyarakat yaitu seseorang dapat menjadi kiai karena beberapa alasan, yaitu diterima oleh masyarakat sebagai kiai, banyak orang datang minta nasehat, dan banyak orang tua mengirimkan anaknya supaya belajar kepadanya. ${ }^{9}$

Keberhasilan pesantren tidak lepas dari kepemimpinan kiai yang terus melakukan berbagai strategi yang dianggap efektif dan efisien dalam mencapai tujuan sebuah lembaga yang dipimpinnya dan melahirkan santri sebagai sumber daya manusia yang berkarakter. Dalam konteks ini, terdapat sosok kepemimpinan kiai Pondok Pesantren An Nur, Ngrukem, Bantul, Yogyakarta yang mampu membawa kemajuan pesat dari masa ke masa tidak lepas dari sosok kepemimpinan KH. Nawawi Abdul Aziz atau yang lebih akrab dipanggil Mbah Nawawi. Keberhasilan beliau tidak hanya dalam mengelola pondok pesantren dan keberhasilan dalam pengajaran tahfidz Al-Qur'an yang menjadi ciri khas pesantren tersebut, tapi juga keberhasilan beliau dalam membentuk karakter Aswaja kepada para santri di Pondok Pesantren An Nur Ngrukem. ${ }^{10}$

Walaupun KH. Nawawi Abdul Aziz pengasuh pondok pesantren An Nur Ngrukem telah wafat, namun tidak lantas turun dalam konteks kualitas pengajaran dan kuantitas santrinya. Justru yang terjadi adalah pesantren ini semakin berkembang dan meningkat dari hari ke hari. Selain pendidikan non formal seperti madrasah diniyah, TPQ, pengajian di masyarakat, tapi juga semakin berkembangnya lembaga pendidikan formalnya, mulai dari

\footnotetext{
${ }^{6}$ Rustam dan Ahmad Shofiyuddin Ichsan, "Pendidikan Islam Berbasis Kearifan Lokal”,33.

7 Zamakhasi Dhofier, Tradisi Pesantren, (Studi tentang Pandangan Hidup Kiai dan Visinya mengenai Masa Depan Indonesia cet. ke-9), (Jakarta : LP3S, 2015), 1-2.

${ }^{8}$ Nurcholis Madjid, bilik-bilik Pesantren Sebuah Potret Perjalanan, (Jakarta: Paradigma, 1997), 465.

9 Zamakhasi Dhofier, Tradisi Pesantren, (Studi tentang Pandangan Hidup Kiai dan Visinya mengenai Masa Depan Indonesia cet. ke-9), 93-94.

${ }^{10}$ Hasil observasi di pondok pesantren An Nur Ngrukem Bantul pada tanggal 1 januari 2020 jam $09.00 \mathrm{~s} / \mathrm{d}$ 11.00 wib.
} 
Madrasah Ibtidaiyah (MI), Madrasah Tsanawiyah (MTs), Madrasah Aliyah (MA), sampai pada perguruan tinggi yang dahulu bernama Sekolah Tinggi Ilmu Al-Qur'an (STIQ) sekarang Institut Ilmu Al Qur'an (IIQ An Nur). Pada titik ini, peran strategi kepemimpinan kiai sangat penting dalam pengembangan keilmuan dan pembentukan karakter santri di Pondok Pesantren An Nur Ngrukem. ${ }^{11}$

Selain itu, peneliti memperlihatkan bahwa wilayah Dusun Ngrukem merupakan kampung santri. Yakni santri dan masyarakat sekitar memiliki perilaku religius dan taat dalam menjalankan agama dalam kehidupan sehari-hari, bahkan masyarakat cenderung terus mengamalkan Al-Qur'an dengan mengkaji, mengaji, dan menghafalnya. Hal ini sesuai apa yang diajarkan oleh KH. Nawawi Abdul Aziz, selaku pengasuh dan pendiri pondok pesantren An Nur, bahwa berdirinya pesantren di wilayah Ngrukem adalah berkah dan bantuan penuh dari masyarakat sekitar. Semasa kepemimpinan KH. Nawawi hingga kini, pesantren dan masyarakat hidup harmoni berdampingan. Hal ini dibuktikan pendelegasian santri untuk ikut kegiatan siskamling atau ronda dan dengan diperbolehkan santri berinteraksi dengan masyarakat lainnya. ${ }^{12}$

Keberadaan Pondok Pesantren An Nur Ngrukem yang telah ramai dengan kegiatan keagamaan itu mencerminkan bernuasa wilayah santri. Kondisi sosial keagamaan tersebut masih terlihat sampai saat ini walaupun pengasuh awal KH. Nawawi Abdul Aziz telah wafat, perjuangan dakwah melalui jalur pendidikan itu sekarang masih terus dilanjutkan oleh ahli warisnya seperti istri dan putra-putranya sebagai dewan dzuriyah, sehingga semakin lama pondok pesantren berdiri dan berkembang, semakin antusias masyarakat untuk terus menjalankan perilaku keagamaan di wilayah tersebut.

Berdasarkan berbagai uraian di atas, peneliti merasa sangat tetarik untuk mengkaji lebih mendalam sosok kiai karismatik dan multi talenta ini khususnya tentang strategi kepemimpinan KH. Nawawi Abdul Aziz dalam membentuk karakter Aswaja (Ahlussunnah Wal Jama'ah) kepada santrinya di Pondok Pesantren An Nur Ngrukem. Selain itu, juga diuraikan bagaimana dampak yang ditimbulkan dalam pembentukan terhadap pemikiran keagamaan santri dan perubahan perilaku santri dalam keberagaman sosial masyarakat.

\section{Metode Penelitian}

Jenis penelitian ini merupakan kajian field research (penelitian lapangan) dengan menggunakan pendekatan kualitatif. pendekatan kualitatif menjadi bekal peneliti menuju ke

${ }^{11}$ Hasil observasi di pondok pesantren An Nur Ngrukem Bantul pada tanggal 1 januari 2020 jam $09.00 \mathrm{~s} / \mathrm{d}$

${ }^{12}$ Observasi pada Desember 2019 pukul $10.00-13.00$ WIB.

268 | IQ (Ilmu Al-qur'an): Jurnal Pendidikan Islam| Volume 3 No.02 2020 
lapangan dalam rangka melakukan pengamatan atau oservasi mengenai suatu peristiwa yang terjadi, yakni melihat langsung Strategi Kepemimpinan Kiai dalam Membentuk Karakter Aswaja. Lokasi tempat Penelitian ini dilakukan di Pondok Pesantren An Nur. Lokasi pondok beralamat di Dusun Ngrukem Desa Pendowoharjo Kecamatan Sewon Kabupaten Bantul Daerah Istimewa Yogyakarta

Metode pengumpulan data merupakan langkah utama dalam penelitian. Pengumpulan data dilakukan dengan tiga macam, yaitu observasi, wawancara, dan dokumentasi. Pertama, Observasi dalam hal ini peneliti melakukan pengamatan secara langsung di lapangan sebanyak tiga kali. Kedua, Interview atau wawancara adalah peneliti melakukan wawancara mendalam kepada beberapa informen penting untuk mengetahui perkembangan dilapangan seperti personal dengan pimpinan pesantren, pengurus, pengajar, santri, dan masyarakat di sekitar pesantren. Ketiga, yakni peneliti menggali informasi dari berbagai media baik berupa foto kegiatan, koran, website, istagram, karya-karya dan media lainnya yang terkait. Selain itu, membutuhkan analisis data hasilnya dapat tersistematis. Adapun Analisis data kualitatif yang dipakai dalam penelitian ini adalah menggunakan model Miles dan Huberman, yakni menganalisa data melalui tiga tahapan, yakni mereduksi data (data reduction), mendisplay data (data display) dan mengambil kesimpulan (conclusion drawing/virificication) ${ }^{13}$. Kesimpulan juga diverifikasi selama penelitian berlangsung. Makna-makna yang muncul dari data harus diuji kebenarannya, kekokohannya, dan kecocokannya. ${ }^{14}$

\section{Implementasi}

Dari hasil wawancara mendalam, peneliti melakukan analisa dengan teori Max Weber terkait strategi kepemimpinan kiai di Pondok Pesantren An Nur Ngrukem. menurut Nurul Azizah, kepemimpinan yang dimiliki seorang kiai dapat dikaji menggunakan teori kepemimpinan dari Max Waber. Max Weber membagi tipologi kepemimpinan berdasarkan teori otoritas menjadi tiga, yaitu karismatik, tradisional, dan rasional-legal. ${ }^{15}$

Hal senada menurut Sulaiman Qurdi dalam Zainal Arifin, bentuk teori otoritas yang mempunyai tiga ciri khas, Karismatik sumber Pengaruh (emosional) dengan kebiasaan kepemimpinan mengalami Perubahan. Sedangkan Tradisional sumber Non-rasional dan Legal (Rasional) sumber Rasional yang kebiasaan lebih pada Pribadi/perorangan dan Kekuasan impersonal yang perubahannya sama-sama dinamis. ${ }^{16}$

Sehingga otoritas kepemimpinan karismatik sangat dipengaruhi oleh ketaatan dari pengikutnya karena sosok kepribadiannya. Otoritas kepemimpinan tradisional sangat dipengaruhi oleh kebiasaan masyarakat tertentu. Teori kepemimpinan dari Max Waber sebagai acuan dasar bagi peneliti dalam melakukan proses penelitian pada saat di lapangan dan mengolah data hasil penelitian.Kiai yang dimaksud adalah KH. Nawawi Abdul Azis karena beliau sudah wafat, maka hasil wawancara mendalam atas ahli warisnya

${ }^{13}$ Sugiyono, Metode Penelitian Pendidikan (Bandung : Alfabeta,.2010), 337.

${ }^{14}$ M.B. Miles. Dan M. Huberman, Analisis Data Kualitatif, (terj.) oleh Tjetjep Rohendi Rohidi, (Jakarta: UI-PRESS, 1992), 16-20. 75.

${ }^{15}$ Nurul Azizah, Artikulasi Politik Santri dari Kiai Menjadi Bupati, (Yogyakarta: Pustaka Pelajar, 2013),

16 Zainal Arifin, ...., 134. 
Menurut John M. Echols dan Hassan Shadily, strategy diartikan strategi, ilmu siasat (perang) atau siasat akal. ${ }^{17}$ Strategi ini memiliki keterkaitan dengan pengambilan sebuat keputusan dalam jangka pendek atau jangka panjang melalui cara pengamatan terhadap peluang dari luar. ${ }^{18}$ Sedangkan dalam kontek keberhasilan strategi dari Sosok KH Nawawi Abdul Azis itu faktanya tidak terlepas dari keteladan yang diberikan atas pembiasaan prilaku keseharian selama hidupnya. Bukan karena dari banyaknya tiori ataupun ceramahnya yang diberikan kepada para santri.

KH. Nawawi memiliki lima strategi yang dinilai efektif sebagai langkah-langkanya dalam upaya membentuk karakter Aswaja para santrinya. Strategi merupakan sebuah cara untuk memudahkan mencapai keberhasilan dalam membentuk karakter santri sebagai pondasi diri para santri di tengah-tengah perkembangan zaman era industri 4.0 saat ini. Berdasarkan hasil wawancara yang mendalam kepada ahliwaris, sekretaris pribadi, dan pengurus pondok pesantren An Nur tentang Strategi KH. Nawawi Abdul Aziz dalam Membentuk Karakter Aswaja kepada Para Santrinya adalah sebagai berikut:

\section{Strategi Kepemimpinan KH. Nawawi Abdul Azis Keteladanan}

Keteladanan pemimpin, pembawaan kepemimpinan dapat dipengaruhi oleh kepribadian sang kiai Nawawi merupakan cara yang paling efektif dalam membentuk karakter santri. Karena, integritas keperibadian Kiai Nawawi merupakan cerminan bagi santri. Kiai Nawawi memberikan contoh bil hal yang baik dari sikap dan prilaku meliputi istikamah ibadah ataupun amaliyah, tawadhu' kesederhanaan, dan kemandirian serta etika menghormati tamu. Keteladan (uswatun hasanah) ini merupakan cara mendidik yang dimulai dari kepribadian kiai Nawawi sendiri dan terus berkhidzmat kepada Allah SWT dalam membimbing santri dan masyarakat untuk beriman dan bertakwa kepada-Nya.

Contoh keteladanan yakni, pertama, istikamah, bentuk istakamah ini dinilai efektif dan mudah diikuti dan diteladani langsung oleh para santri. Istikamah merupakan hal rutin dilaksanakan dan tidak semua manusia mampu melaksanakannya. Istikamah memudahkan orang awam dalam hal ini para santri untuk mengikuti tuntunan dari sang kiai. Keistikamahan ini sebagai strategi KH. Nawawi dalam membentuk karakter santri melalui bil hal, ${ }^{19}$ yaitu secara langsung dengan keteladanan mulai dari pembiasaan perilaku KH. Nawawi.

\footnotetext{
${ }^{17}$ John M. Echols dan Hassan Shadily, kamus Inggris-Indonesia, (Jakarta: PT Gramedia Pustaka, cet XXVI 2005), 560 .

18 Azhar Arsyad, pokok-pokok pendidikan, pengetahuan, praktis bagi pemimpin dan eksekutif, ( Yogyakarta, Pustaka Pelajar, cet III 2012), 27

${ }^{19}$ Bil hal adalah sesewatu kebaikan yang di lakukan dengan tindakan nyata. 270 | IQ (Ilmu Al-qur'an): Jurnal Pendidikan Islam| Volume 3 No.02 2020
} 
Kepemimpinan kiai adalah kepemimpinan karismatik dengan semangat teladan, dimana tokoh kiai diyakini masyarakat sebagai orang yang tidak hanya ahli dalam bidang agama tetapi dipandang mampu memberikan solusi di bidang sosial dan keagamaan, bahkan juga mampu untuk berkontribusi pada bangsa dengan meluasnya tujuan pendidikan nasional. Hal itu ditandai dalam membangun karakter generasi muda dengan pendidikan ketulusan, pendidikan kemandirian, pendidikan persaudaraan, dan pendidikan disiplin. ${ }^{20}$

\section{Pemahaman Islam Moderat}

Persolan perang Siffin antara tentara Ali dan tentara Mua'wiyah yang berujung pada peristiwa al-tahkim atau arbitrase. ${ }^{21}$ Perlu diketahui bahwa Khawarij merupakan pengikut Ali Ibn Talib yang keluar meninggalkan barisan, karena tidak setuju atas kebijakan Ali Ibn Talib yang bersedia untuk arbitrase. ${ }^{22}$ Kaum Murji'ah merupakan pendukung setia Ali Ibn Talib dalam Islam dikenal dengan nama Syi'ah. ${ }^{23}$ Kaum Mu'tazilah merupakan golongan yang menggunakan akal dalam persoalan teologi. ${ }^{24}$

Kaum Mu'tazilah disamping golongan minoritas, juga tidak kuat berpegangan pada sunnah atau hadis. Hal ini menimbulkan term aliran-aliran al-Asyari dan al-Maturidi menentang ajaran Mu'tazilah. Adapun, aliran tiologi al-Asyi'ari itu dibentuk oleh Abu Hasan al-Asy'ari yang pernah 40 tahun mengikuti paham aliran Mu'tazilah. ${ }^{25}$ KH. Nawawi Abdul Azis menambahkan istilah Ahlus Sunnah Wal Jama'ah (Aswaja) di kawasan negara-negara di Timur Tengah dikenal dengan sebutan kata sunni. ${ }^{26}$

Pentingnya pemahaman Islam moderat bagi santri melalui pengajian, kajian wetonan dan kajian lapanan penyelenggaraan kurikulum kitab kuning ala Sunni. penyelenggaraan kurikulum yang dilakukan pada masa kepemimpinan KH Nawawi Abdul Azis kemudian diwarisi oleh dewan dzuriah. Sehingga para santri menjadi bagian dalam menampilkan wajah Islam yang damai, Islam yang ramah dan morerPasi beragama sekaligus membentingi diri dari faham radikal dan fundamental.

Sebagi upaya pemahaman itu dengan penyelenggaraan kurikulum menggunakan kitab klasik/kuning ala Sunni. Dalam kurikulum kajian kitab kuni ini dibagi dua macam yaitu kajian wetonan dan kajian lapanan. Adapun rincian sebagai berikut:, pertama, Pengajian Wetonan Ahad Pon di Pondok Pesantren An Nur Ngrukem. Sosok KH. Nawawi yang sangat 'alim dan memiliki pengaruh ini sangat memudahkan cara mentransfer nilai-nilai keagamaan. Nilai itu tidak hanya melalui pengajaran tahfidzul Qur'an, tapi juga membentuk karakter Aswaja An-

\footnotetext{
${ }^{20}$ Mohammad Masrur, Figur Kyai dan Pendidikan Karakter di Pondok Pesantren, Jurnal Ilmiah Pendidikan: Volume 01; Nomor 02, Desember 2017, 6.

${ }^{21}$ Harun Nasution, Tiologi Islam: Aliran-aliran Sejarah Analisa Perbandingan, (Jakarta: Pernerbit UIPress, 2018), 7

${ }^{22}$ Harun Nasution, Tiologi Islam: Aliran-aliran Sejarah Analisa Perbandingan, 13

${ }^{23}$ Harun Nasution, Tiologi Islam: Aliran-aliran Sejarah Analisa Perbandingan, 24

${ }^{24}$ Harun Nasution, Tiologi Islam: Aliran-aliran Sejarah Analisa Perbandingan, 40

${ }^{25}$ Harun Nasution, Tiologi Islam: Aliran-aliran Sejarah Analisa Perbandingan, 64-65

${ }^{26}$ Nawawi Abdul Aziz, 'Alaikum Bissawadil A'dzom, Cet. 4, (Kudus: Menara Kudus, 2014), 5.
} 
Nahdliyah pada santri melalui kajian kitab-kitab kuning yang merujuk kepada ajaran ahlussunnah waljamaah, baik materi hafalan qur'an, fiqih, tauhid, akhlaq maupun aqidah. ${ }^{27}$ Seperti yang dikatakan oleh menantu KH. Yasin Nawawi yaitu KH. Rumaizizat yang akrab disapa Gus Rum. Gus Rum sebagai pengampu kajian kitab kuning warisan pengajian wetonan dari KH. Nawawi Abdul Azis. ${ }^{28}$ Gus Rum memiliki jadwal kajian setiap hari ahad mengenalkan tentang tentang ihya'ululu muddin setiap ahad sore di Komplek Nurul Huda, di pondok ada ahad pon kitab Al-Hikam yang dirintis oleh KH. Nawawi.

Kedua, Pengajian Lapanan Ahad Pon di Pondok Pesantren An Nur Ngrukem berupa pengajian lapanan Ahad Pon. Sejarah Pengajian lapanan ini selain program unggulan, tapi juga strategi kepemimpinan KH. Nawawi sebagai media silaturrahmi dengan santri ekternal (masyarakat) dan juga diikuti oleh santri intrenal (mukim). Cara silaturrahim ini dinilai sangat efektif dalam membentuk karakter Aswaja. Pengajian lapan Ahad pon itu selain diikuti oleh santri mukim dan santri dari masyarakat, tapi juga pada perkembanagannya diikuti oleh santri dari kalangan guru-guru madrasah dan wali murid. . ${ }^{29}$

Selain itu itu, di dalam pendidikan keagamaan kitab kuning mengalami Perkembangan Kajian keislaman semenjak diampu oleh Gus Rum semakin meluas wilayah binaannya seperti di Gunung Kidul dan Disantan, Kitab Safinah diajarkan jelas itu ajaran Aswaja, di Masjid Agung itu mengajarkan kitab Hadis Bulughul Marom setiap malam sabtu atas permintaan Kemenag Kabupaten Bantul dan didukung oleh Pemda Kabupaten Bantul, ada juga di Kulon Progo. Kemudian kajian kitab Al hujjah Aswaja Karya KH. Ali Maksum Krapyak yang diselenggarakan oleh LDNU Kecamatan Sewon. Kedepannya akan diminta juga di Majlis Taklim Al-Hasan, Jokerten, Timbulharjo, Sewon. ${ }^{30}$

Pemahaman Pengetahuan Islam Aswaja, sistem yang berada di pondok pesantren An Nur yaitu santri diajak melestarikan tradisi yang sudah menjadi karakteristik ajaran Islam rahmatan lil 'alamim dengan cara pengajar, pemahaman baik, santri juga diberi tahu tentang pemahaman yang takfiri (seneng mengkafirkan), menyimpang termasuk mengenai pemahaman radikal. Selama seminggu sekali dijelaskan tentang pemahaman mengapa harus tahlil, mengapa berziarah kubur, pentingnya istiqhatsah, membaca shalawat al-barjanji termasuk mengenai peringatan hari besar Islam. ${ }^{31}$

${ }^{27}$ Wawancara KH. Muslim Nawawi selaku pengasuh pondok pesantren An Nur Ngrukem pada Sabtu, 18 Januari 2020.

${ }^{28}$ Observasi dan wawancawa Gus Rum di ndalemnya komplek Nurul Huda pondok pesantren An Nur pada tanggal 7 februari 2020.

${ }^{29}$ Wawancara KH. Muslim Nawawi selaku pengasuh pondok pesantren An Nur Ngrukem pada Sabtu, 18 Januari 2020.

${ }^{30}$ Observasi dan wawancawa Gus Rum di ndalemnya komplek Nurul Huda pondok pesantren An Nur pada tanggal 7 februari 2020.

${ }^{31}$ Hasil observasi dan wawancara dengan KH. Rumaizijat, S.Pd.I atau Gus Rum di kediamannya, pada tanggal 31 Januari 2020.

272 | IQ (Ilmu Al-qur'an): Jurnal Pendidikan Islam| Volume 3 No.02 2020 


\section{Menumbuhkan Rasa Toleransi}

Menumbuhkan rasa toleransi, melaui buku pegangan berjudul alaikum bissawadil a'dham bertujuan mengajarakan sikap dan tindakan toleransi yang menghargai terhadap keragaman masyarakat baik aliran, agama, budaya, etnis maupun warna kulit. KH Nawawi Abdul Azis menumbuhkan rasa toleransi tidak hanya santri mukim saja melainkan juga santri masyarakat yaitu selama berkhidmat di oganisasi Nahdlatul Ulama, mengajarkan tentang apa perilaku atau amaliah yang sering dilakukan. Sehingga, akhir-akhir simbah (KH. Nawawi) jadi Syuri'ah PWNU DIY, kemudian baru menulis buku Aswaja yang berjudul 'Alaikum Bissawadi A'dham untuk pedoman santri dan masyarakat. Sebab, dulu belum ada tata cara ubudiyah khusus, dulu caranya hanya mengajarkan amaliah keseharian yang dilakukan, seperti banyak ngaji, ziarah kubur, genduren, tahlilan, yasinan, berzanzenan. Kalau sekerang zamannya beda, apa-apa mana dalilnya, seneng membit'ahkan bahkan mengkafirkan. ${ }^{32}$

Di dalam buku 'Alaikum Bissadhil A'dham warisan KH. Nawawi Abdul Aziz yang akrab dipanggil simbah Nawawi. Buku tersebut memuat tentang ajaran Aswaja yang harus kita pahami sudah dihidangkan oleh beliau simbah kiai Nawawi, walaupun hanya sekedar garis besarnya, tetapi semua itu sangat penting. garis besar adalah gambaran umumnya. Seperti konsep aqidah As'ariyah, konsep ini memiliki keterkaitan terhadap qadha dan qadhar yang merupakan rukun iman yang nomor enam. ${ }^{33}$

Pengajaran Aswaja yang ketat melalui pembelajaran dan keteladanan dan diperkuat wawasan Aswaja agar dapat meinternalisasi ke dalam kepribadian para santri melalui buku karya KH. Nawawi berjudul'Alaikum Bissawadil A'dzom. Hal ini memperlihatkan bahwa pembentukan karakter Aswaja terhadap santri di pondok pesantren An Nur Ngrukem terjaga dengan baik. Selain itu, karakter aswaja ini yang diharapkan akan menjadi ciri khas pembeda dari lembaga pendidikan Islam lainnya.

\section{Nilai Cinta Tanah Air}

Nilai cinta tanah air, media cerita juga sebagai salah satu strategi dalam mendoktrin jiwa nasionalisme santri agar mempunyau rasa cinta pada tanah air Indonesia dan meneladani perjuangan para kiai-kiai pesantren dalam membela tanah air dengan mengisi kemerdekaan di era industri 4.0. Sehingga, santri akan berfikir dan menunjukkan bersikap yang lebih mengutamakan kepentingan bangsa dan negaranya dari pada kepentingan pribadi atau golongan.

${ }^{32}$ Wawancara dengan Ketua Yayasan Ma'had An-Nur, KH. Yasin Nawawi, pada tanggal 07 Februari 2020 di kediamannya Ndalem Pondok pesantren An Nur, komplek Nurul Huda.

${ }^{33}$ Wawancara dengan Ustadzah Istiqomah yang dilaksanakan pada jumat, 14 februari 2020 di komplek al-Hikmah, Pondok Pesantren Annur Putri Pusat. 
Doktrinasi Cerita mengenai peran Kiai-Kiai Pondok Pesantren yang gigih berjuang Membela Tanah Air. Perjuangan para kiai-kiai pondok pesantren terdahulu yang tidak hanya memperjuangkan aqidah Aswaja dan ikut memperjuangkan kemerdekaan bangsa Indonesia”. 34

KH Nawawi Abdul Azis mampu mendasari pemikiran keagamaan santri - santri melalui dunia cerita perjuangan para kiai yang heroik itu, artinya santri diharapkan tidak hanya meneladani keahlian atau kepintaran para kiai di bidang ilmu tafaqquh fiddin (pemahaman agama) saja, tapi juga menambah wawasan menanamkan untuk memiliki jiwa nasionalis kepada santri yang disisipkan Mbah Nawawi dalam forum pengajian dan setiap kesempatan lainnya.

\section{Nilai Religius}

Religius, yaitu menerapkan sikap dan prilaku yang mengamalkan ajaran agama seperti implementasi pembiasaanp praktik ibadah-ibadah ala sunni kepada para santri di pondok pesantren An Nur Ngrukem, seperti amaliayah membaca simthud duror, membaca sholawat al barzanji, dzikir tahlil, ziarah kubur, mencintai ahlul bait dan menghormati seluruh sahabat Nabi tanpa terkecuali sebagaimana Imam Abu Hanifah.

Dari pemaparan strategi kepemimpinan di atas tidak terlepas dari kredibelitas $\mathrm{KH}$ Nawawi Abdul Azis sebagai pimpinan pesantren yang berusaha mewujudkan visi, tujuan dan sasaran, salah satunya adalah membentuk karakter Aswaja di pondok pesantren An Nur Ngrukem.

Selain adanyan pembiasaan dalam implementasi pembiasaan ibadah-ibadah kepada para santri di pondok pesantren An Nur Ngrukem. Secara ahwal juga lebih pada nasehat bil hal melaksanakan aswaja seperti ikhlas, istikamah, al I'tidal (tegak lurus/proposional), at Tawassuth (Moderation), at Tawazun (Keseimbanagan), at Tasamuh (Toleransi), dan setiap ada kegiatan masyarakat dilibatkan". ${ }^{35}$

Berbagai hal di atas, merupakan strategi kepemimpinan KH. Nawawi Abdul Azis untuk pembiasaan ibadah dengan mendorong para santri agar terbiasa mengamalkan agamanya yang dilandasi nilai-nilai karakter Aswaja An Nahdliyah dalam kehidupan sehari-hari di pondok pesantren An Nur Ngrukem. Pembisaan ibadah ini sebagai salah satu cara efektif dalam membentuk karakter Aswaja santri dengan memberikan keteladanan melalui bil hal di atas menjadi salah satu cara yang secara langsung yang dilakukan bersama para santri dalam aktivitas selama di pondok pesantren An Nur Ngrukem.

Santri sebagai garda terdepan dalam menjaga tradisi Aswaja (Ahlussunnah Wal Jama'ah An Nahdliyah) yang telah diwariskan KH. Nawawi di manapun, dalam kondisi apapun dan sampai kapanpun. Oleh karena itu, diharapkan dapat meneladani kepribadian, keistiqamahan simbah Nawawi dalam kepada berkhidmat kepada Allah SWT. Kemudian dalam berdakwah harus terus membangun tradisi yang baik, melakunan inovasi dan kreatifitasa

\footnotetext{
${ }^{34}$ Wawancara dengan Ustadz Yazidun Ni'am, pengurus harian, di kantor pondok pesantren An Nur pusat pada tanggal 21 Januari 2020.

35 Wawancara dengan KH. Rumaizijat, S.Pd.I atau Gus Rum di kediamannya, pada tanggal 31 Januari 2020.

274 | IQ (Ilmu Al-qur'an): Jurnal Pendidikan Islam| Volume 3 No.02 2020
} 
dalam menyebarkan nilai-nilai kebaikan bagi sesama serta dalam membimbing masyarakat untuk beriman dan bertakwa kepada Allah SWT. ${ }^{36}$

\section{Kesimpulan}

Berikut kesimpulan berdasarkan teori kepemimpinan Max Weber, maka dapat dianalisa sebagai bentuk kepemimpinan KH Nawawi Abdul Azis dalam dunia pendidikan pesantren para penghafal Alqur'an dan pembentukan karakter Aswaja para santri di Pondok Pesantren An Nur. KH Nawawi Abdul Azis memiliki strategi mengelola lembaga pendidikan pondok pesantren dengan lima cara yaitu selama kepemimpinan KH. Nawawi senantiasa istikamah dalam segala hal, baik ibadah, amaliah keseharian, kemudian penyelenggaraan kurikulum menggunakan kitab kuning ala Sunni (ahlussunnah wal jamaah) baik wetonan maupun lapanan, menulis buku 'alaikum bissawadil 'adham untuk pembelajaran agama bagi santri karena sesuai tuntutan zaman dan karya-karya lain untuk para santri dan masyarakat. Selain itu, dalam setiap kesempatan KH. Nawawi menceritakan jasa-jasa atas peran kiai-kiai pondok pesantren dalam membela tanah air Indonesia dan memberi teladan serta menerapkan pembiasaan ibadah-ibadah seperti kebiasaan KH. Nawawi Abdul Azis yang tepat waktu dalam shalat dan amaliah-amaliah bernuansa Aswaja, seperti membaca sintut duror, membaca shalawat al-barzanzi, dzikir tahlil, ziarah kubur, moderasi beragama, dan toleransi.

\section{Saran}

Kepada Pengelola Pondok Pesantren An Nur, Ngrukem, Bantul, peneliti berharap supaya warisan tentang strategi kepemimpinan KH. Nawawi tetap dilestarikan dan terus digali strategi lainnya dalam membentuk karakter Aswaja santri, termasuk mengelola pondok pesantren An Nur Ngrukem. Kepada Para Santri Pondok Pesantren An Nur, Ngrukem, Bantul, peneliti berharap supaya dapat meneladani dan mengembangkan apa yang telah menjadi warisan strategi kepemimpinan KH. Nawawi sesuai pada zaman Anda kelak dikemudian hari.

\section{Daftar Pustaka}

Arsyad, Azhar, cet III 2012. pokok-pokok pendidikan, pengetahuan, praktis bagi pemimpin dan eksekutif, Yogyakarta, Pustaka Pelajar

Azizah, Nurul, 2013. Artikulasi Politik Santri dari Kiai Menjadi Bupati, Yogyakarta: Pustaka Pelajar

Arifin, Zainal, "Kepemimpinan Kiai dalam Ideologisasi Pemikiran Santri di PesantrenPesantren Salafiyah Mlangi Yogyakarta", Inferensi Jurnal Penelitian Sosial Keagamaan, IAIN Salatiga, 9 (2), Desember 2015: 360.

Dhofier, Zamakhasi. 2015, Tradisi Pesantren, (Studi tentang Pandangan Hidup Kiai dan Visinya mengenai Masa Depan Indonesia cet. ke -9), Jakarta : LP3S

\footnotetext{
${ }^{36}$ Wawancara dengan Ketua Yayasan Ma'had An-Nur, KH. Yasin Nawawi, pada tanggal 07 februari 2020 di kediamannya Ndalem Pondok pesantren An Nur, komplek Nurul Huda.
} 
Rustam

Echols, John M. dan Hassan Shadily, cet-XXVI 2005. Kamus Inggris dan Indonesia, Jakarta : PT. Gramedia Pustaka Utama

Miles, M.B.. Dan M. Huberman, 1992. Analisis Data Kualitatif, (terj.) oleh Tjetjep Rohendi Rohidi, Jakarta: UI-PRESS

Madjid, Nurcholis, 1997, bilik-bilik Pesantren Sebuah Potret Perjalanan, Jakarta: Paradigma Maragustam, 2018, Filsafat Pendidikan Islam, Yogyakarta: FITK UIN Sunan Kalijaga

Masrur, Mohammad, Figur Kyai dan Pendidikan Karakter di Pondok Pesantren, Jurnal Ilmiah Pendidikan :: Volume 01; Nomor 02, Desember 2017, hlm. 6

Nasution, Harun, 2018. Tiologi Islam, (Aliran-aliran Sejarah Analisa Perbandingan), Jakarta: Pernerbit UI-Press

Nawawi Abdul Aziz, 2014. 'Alaikum Bissawadil A'dzom, Cet. 4, Kudus: Menara Kudus

Rustam dan Ahmad Shofiyuddin Ichsan/IQRO: Journal of Islamic Education Vol. 3, No.1, Juli 2020. $1-14$

Sugiono, 2012. Metode Penelitian Pendidikan Pendekatan kontitatif, dan $R \& D$, cet. ke-14, Bandung: Alfabeta

\section{Observasi, Wawancara dan Dokumentasi}

Hasil observasi pada Desember 2019 pukul 10.00 - 13.00 WIB.

Hasil observasi di pondok pesantren An Nur Ngrukem Bantul pada tanggal 1 januari 2020 jam $09.00 \mathrm{~s} / \mathrm{d} 11.00 \mathrm{wib}$

Hasil wawancara denga Muhammad Tamyis, S.Pd.I selaku Lurah Pondok di kantar pengurus pondok pesantren An Nur pada 15 Januari 2020

Hasil wawancara Drs. H. Zainuri, santri masyarakat dan pernah menjadi sekretaris preode rintisan MADIN yang ketuanya adalah KH. Nawawi dikediamannya pada tanggal 26 Januari 2020

Hasil wawancara KH. Muslim Nawawi selaku pengasuh pondok pesantren An Nur pusat pada Sabtu, 18 Januari 2020.

Hasil wawancara dengan Ketua Yayasan Ma'had An-Nur, KH. Yasin Nawawi , pada tanggal 07 Januari 2020

Hasil wawancara dengan Ketua Yayasan Ma'had An-Nur, KH. Yasin Nawawi , pada tanggal 17 Januari 2020

Hasil wawancara dengan Ustadz Yazidun Ni'am, pengurus harian, di kantor pondok pesantren An Nur pusat pada tanggal 21 Januari 2020. 
Hasil wawancara dengan KH. Rumaizijat, S.Pd.I atau Gus Rum di kediamannya, pada tanggal 31 Januari 2020.

Hasil wawancara dengan KH. Rumaizijat, S.Pd.I atau Gus Rum di kediamannya, tanggal 7 Februari 2020

Hasil wawancara dengan Ustadzah Istiqomah yang dilaksanakan pada jumat, 14 februari 2020 di komplek al-Hikmah, Pondok Pesantren Annur Putri

Hasil wawancara dengan Fauzia Aulia, santri sejak Madrasah Aliah sampai kuliah di IIQ An Nur Yogyakarta

Hasil wawancara dengan Ahmad Jamaluddin selaku santri yang mahasiswa yang aktif di Korps Dakwah mahasiswa (Korda) IIQ An Nur pada tanggal 28 Januari 2020.

Hasil wawancara dengan Ustadz Qowim Musthofa Al-Hafidz, MSI di pondok pesantren An Nur Ngrukem yang juga salah satu penulis buku biografi KH Nawawi Abdul Azis dan menjadi Dosen IIQ An Nur Yogyakarta di kediamannya pada tanggal 24 Februari 2020. Hasil dokumentasi Yayasan An Nur Sejarah Berdirinya Pondok Pesantren, dikutip pada tanggal 17 Januari 2020 
Rustam

278 | IQ (Ilmu Al-qur'an): Jurnal Pendidikan Islam| Volume 3 No.02 2020 